（東京帝國大學工學部脽用需氣化學及光化學研究室）（昭和七年六月八日受理）

\title{
交流㶾解に依る二酸化 マンガンの製法
}

龜川直人 - 飯田廣

緒言

著者が種々なる二酸化マンガンの製法を矿究中著者の一人（飯田）はマンガン監の水溶液を適當なる條件の 下に交流を用ひて電解寸れば二酸化マンガンが簡易に生成し得らるることを發見せり此方法は二酸化マンガン

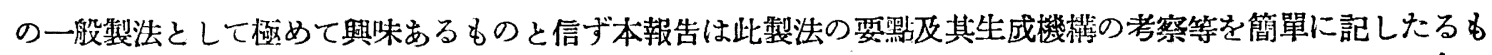
のなり

從來或稙のマンガン暨を直流にて電解寸るときは陽極に二酸化マンガンの生ずる事は既知なれども变流を以 て能く之を䉆し得る事は未知の事なりき

方 法 要 領

硫酸或は硝酸のマンガン盤の如き可溶性マンガン盟の水溶液に白金或は過酸化鉛の兩極を入れ之に㚆流を通 じて電解す交流は市內動力線より之を取りて可なり電極の電流密度は大なるを可とし白金の場合に $1 \mathrm{~cm}^{2} に$ 數アムペア程度とす電解溫度は $40^{\circ} \mathrm{C}$ 程を可とし電解液は弱酸性を可とす

マンガン整としては硝酸盤を最便利とす電解の進行に伴ひ $\mathrm{MnO}_{2}$ を主成物とする沘澱が電極面に生じ直ち

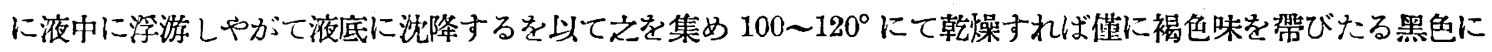
して純度高き二酸化マンガンを得

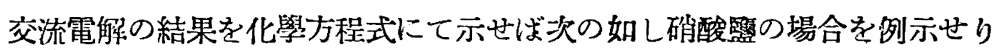

$$
\mathrm{Mn}\left(\mathrm{NO}_{3}\right)_{2}+2 \mathrm{H}_{2} \mathrm{O}=\mathrm{MnO}_{2}+2 \mathrm{HNO}_{3}+\mathrm{H}_{2}
$$

之により電解液中に硝酸を生成するが故に之に粉末日 $\mathrm{MnCO}_{3}$ を逐次加へ行くときは絕えず電解液中に $\mathrm{Mn}\left(\mathrm{NO}_{3}\right)_{2}$ の濃烷を維持することを得て結局は $\mathrm{MnCO}_{3}$ を原料とし次式に相當して $\mathrm{MnO}_{2}$ を製し得ること となるなり

$$
\mathrm{MnCO}_{3}+\mathrm{H}_{2} \mathrm{O}=\mathrm{MnO}_{2}+\mathrm{CO}_{2}+\mathrm{H}_{2}
$$

交流として市內動力線より直ちに之をとり得るを以て非常に便利なり

電極より發生する氣曫の分析

電解酸化の機構を檢するため先づ電㥛より發生する氣鲴を分析せり

直流にて電解する場合には電㥛は或は陽極或は陰極として其極の性質不變なれども交流の場合には一の電極 が陽極とか陰極とか之を一定し得ざること勿論なり今一の電極に就て見るときは或時刻には陰極となり次の時

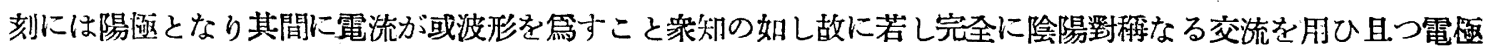
に於ける反應も亦陰陽瓦に對桶的なるときは結局其處には何等電解生成物を生ぜざる筈なり又若し其電極が陰 極となる期間に於ては水素瓦斯を發生し陽極となる期間には酸素瓦期を發生し其他の電極反雇全く無き場合に は結局交流電解に依りて水が電解せられて $2 \mathrm{H}_{2}+\mathrm{O}_{2}$ の比に水素及酸素を生ずべきなり之と晎り若し電解酸化 或は還元が行はるるならば是等の $\mathrm{O}_{2}$ 或は $\mathrm{H}_{2}$ の一部は氣態として發散せず

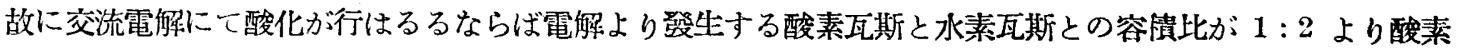
少きを必要とし其比少ければ少きほど電解酸化は巵好なる電流效率にて行はるるなり 
此艾流電解にて二酸化マンガンの生成するを發見せる當初に於ては交流は唯電液を加熱するに役立つのみに あらずや郎ち酸化は主として空氯酸素に体るにあらずやとの疑あり電解液に空㴋の來らざる樣にし或は電㥛を 液底深く沈めて電解を行ひ何處より二酸化マンガンの生成の出來るやを檢し又電極より發生せる瓦斯の分析䘮 行ひたり是等の寅醶の結果此酸化は電解に依り電極に於て行はるるものなることを知れり

下に電極瓦斯の分析の數例を揭ぐ是等の實簽に於ては炭酸マンガンを加へざりしを以て瓦斯中には $\mathrm{CO}_{2}$ 存 せざる筈なり

第一例 硫酸マンガンの場合

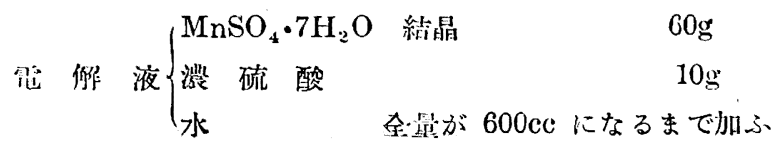

電極瓦斯中に存在を预想せらるるものは $\mathrm{H}_{2}, \mathrm{O}_{2}\left(\mathrm{H}_{2}\right.$ の $\mathrm{x} / 2$ 以下の見达) 及び少量の $\mathrm{O}_{3}$, 電解液中に浴存し 居たる宾氣等なるが故に分析は次の順序にて行ひたり

$\mathrm{A}$ 法 $\left(\mathrm{I}_{A}, \mathrm{II}_{A}, \mathrm{III}_{\mathrm{A}}\right)$

1. $\mathrm{KOH}$ 液吸收(酸性瓦斯吸收)

2. ピロカロール・アルカリ液吸收(酸素吸收)

3. 躰知量い酸絜を加ふ

4. 爆發收縮 $\left(2 \mathrm{H}_{2}+\mathrm{O}_{2}\right)$

5. 再びピロガロール・アルカリ液にて吸收して 過剩酸素の存在を確む
B 法 $\left(\mathrm{I}_{\mathrm{B}}, \mathrm{II}_{\mathrm{B}}, \mathrm{III}_{\mathrm{B}}\right)$

1. $\mathrm{KOH}$ 液吸收

2. 爆發收縮

3. 既知㽬の酸素を加了。

4. 再び爆發收縮

5. 再びビロガロール・アルカリ液にて吸收

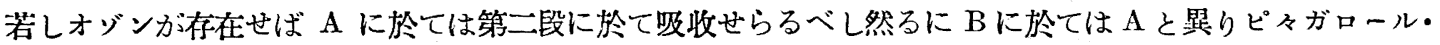
アルカリ夜にて吸收する以前に襮發せしめたるが故にオゾンの如きも此水素との愿發化合に與るべく期待せら る故に若し A と B との分析法にて結果に相當の差を生ずるときは少からざるオげンの存在を認めざるべか らず然るに次に示すが如く兩者の差羙ど無きが故に藷量のオジンは存せざるものと認む（刎諭微量の存在は可 能なるべし)

\section{硫酸マンガン溶液の電解瓦斯}
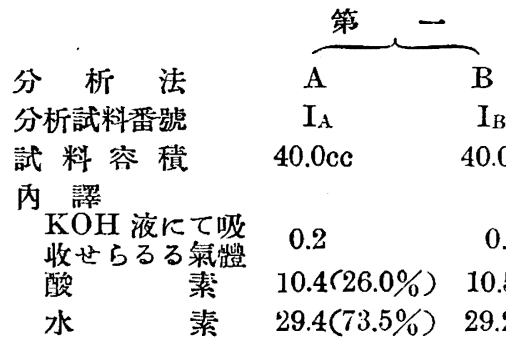

$\mathrm{I}_{\mathrm{A}}$

$40.0 \mathrm{cc}$

$\mathrm{I}_{\mathrm{B}}$

$40.0 \mathrm{cc}$

0.3

$10.4(26.0 \%)$

$29.4(73.5 \%)$

$29.2(73$.

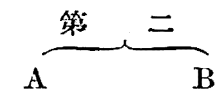

$\mathrm{II}_{\mathrm{A}}$

$40.0 \mathrm{cc}$

0.2

$10.2(25.5 \%)$

$28.8(72.0 \%)$

\section{$\mathrm{II}_{\mathrm{B}}$}

$40.0 \mathrm{cc}$

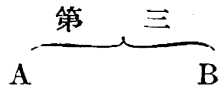

$\mathrm{III}_{\mathrm{A}}$

$34.9 \mathrm{cc}$

0.1

$10.3(25.7 \%)$

0.3

$9.7(27.8 \%)$

酸絜/水素の比 $(1 / \mathrm{X}) \quad 1 / 2.83$

管游效率 $\alpha$

$29.3 \%$

$1 / 2.82$

$29.0 \%$
$29.0(72.5 \%)$

$1 / 2.81$

$23.8 \%$
$24.2(69.4 \%)$

$1 / 2.50$

$20.0 \%$
III $_{B}$

$38.0 \mathrm{ec}$

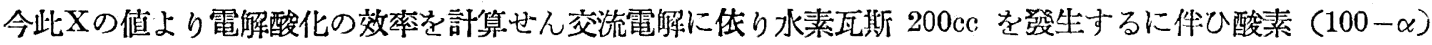
cc を發生せば $\alpha \%$ は郎ち電流效率に當る而して此場合 $1 / \mathrm{X}$ は $(100-\alpha) / 200$ となるが故に 電流效家 $\alpha \%=100 \%-\frac{200}{\mathrm{X}} \%$

之を上表に記せり但し此計算に於ては水素發生は完全に $100 \%$ の電流珓慗を有するものと假定せり

電解瓦斯中には每四必ず少量 (約0.5\%) の $\mathrm{KOH}$ 液に吸收せらるるものを見出せり之は KOH に吸收せら 
るが故に酸性の瓦斯なるべく想像せられ或は $\mathrm{H}_{2} \mathrm{SO}_{4}$ が一部還元せられて $\mathrm{SO}_{2}$ になりたると想像し得れども 此現象は叉 $\mathrm{H}_{2} \mathrm{SO}_{4}$ を有せざる硝酸マンガン溶液の場合にも見出せり結局其正體を明にし得ざりき然れども此 疑間は重要ならずとして追究せず

第二例 确酸マンガンの場合

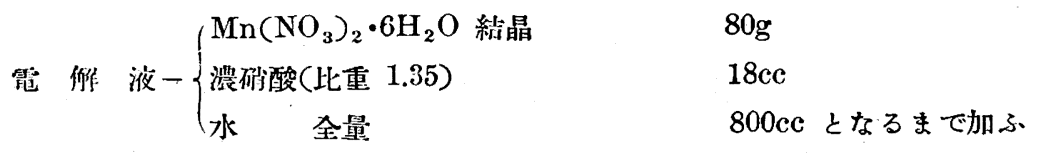

此場合電解瓦斯成分として豫想せらるるものは $\mathrm{H}_{2}, \mathrm{O}_{2}$ の外に确酸基の還元若しくは酸化より來るべき諸氣 咸あり此後者に就き若干の知識を得ることを必要と認め硝酸のみを交流にて電解し電解瓦斯を分析せるに次の 如き結果を得たり分析法は既記 A 法に依れり

矿酸(比雨 1.35 の酸 $18 \mathrm{cc}$ を $800 \mathrm{cc}$ に稀櫂); 電極は白金線

\begin{tabular}{|c|c|c|c|c|c|}
\hline 芸式 & $39.4 \mathrm{cc}$ & & & \multicolumn{2}{|c|}{ 全 量 } \\
\hline $\mathrm{KOH}$ に吸收後 & 39.0 & \multicolumn{2}{|c|}{$\begin{array}{l}\mathrm{KOH} \text { に吸收 } \\
\text { せらるる氣體 }\end{array}$} & $0.4 \mathrm{cc}$ & $=1.0 \%$ \\
\hline $\begin{array}{l}\text { ピロガロール・アル } \\
\text { カリ液に・て吸收後 }\end{array}$ & 26.6 & 酸 & 政 & 12.4 & 31.5 \\
\hline $\begin{array}{l}\text { 酸絜を加以て爆發し } \\
\text { 收宿せる積 }\end{array}$ & 36.8 & 水 & 素 & 24.5 & 62.1 \\
\hline 窒猄 & 2.1 & 主 & 素 & $\begin{array}{r}2.1 \\
39.4\end{array}$ & $\frac{5.1}{100.0}$ \\
\hline
\end{tabular}

之を以て見るときは僅に水素の方が少く電解還元が若干行はるるが如し

以下電解瓦斯の分析を示す分析法は既記の如き A 法及 B 法を用ひたり電解瓦斯中には多少の空素を含有す るを常とす之は瓦斯試料探取に當り小量の空氯を混入したる䉆にはあらず此點充分に注意せり故に恐らく硝酸 の電解還元より來りたるものなるへしし但し今は之を梁く追究せず

硝酸マンガン溶液の電解瓦斯

\begin{tabular}{|c|c|c|c|c|c|c|c|c|}
\hline 霓解傊驗 & 第 & 一 & 第 & 二 & 第 & $\equiv$ & 第 & 四 \\
\hline 分析方 治 & A & B & A & B & Á & B & $\tilde{A}$ & B \\
\hline 分析試驗容積 & $40.1 \mathrm{cc}$ & $40.2 \mathrm{cc}$ & $40.0 \mathrm{cc}$ & $40.0 \mathrm{cc}$ & $40.1 \mathrm{cc}$ & $40.0 \mathrm{cc}$ & $39.6 \mathrm{cc}$ & $40.0 \mathrm{cc}$ \\
\hline $\begin{array}{l}\mathrm{KOH} \text { 液にて吸 } \\
\text { 收せらろ氣唱 }\end{array}$ & 0.1 & 0.2 & 0.2 & 0.2 & 0 & 0 & 0.1 & 0.1 \\
\hline 酸 素 & 7.8 & 7.7 & 9.2 & 9.2 & 9.8 & 9.4 & 9.1 & 9.2 \\
\hline 素 & 31.4 & 31.6 & 29.6 & 29.4 & 28.8 & 29.1 & 29.5 & 29.8 \\
\hline 䋕 & 0.8 & 0.9 & 1.1 & 1.3 & 1.4 & 1.3 & 0.85 & 0.8 \\
\hline 酸素/水絷の此 & $1 / 4.03$ & $1 / 4.10$ & $1 / 3.22$ & $1 / 3.20$ & $1 / 2.94$ & $1 / 3.10$ & $1 / 3.24$ & $1 / 3.24$ \\
\hline 電流效 & $50.4 \%$ & $51.2 \%$ & $37.9 \%$ & $37.5 \%$ & $32.0 \%$ & $35.4 \%$ & $38.2 \%$ & $38.2 \%$ \\
\hline
\end{tabular}

以上に依りて電解酸化が行はれることを示し得たり

但し上上は特に炭酸マンガンを添加すること無くして行ひたるを以て液中よりマンガンは減少し硝酸が次第

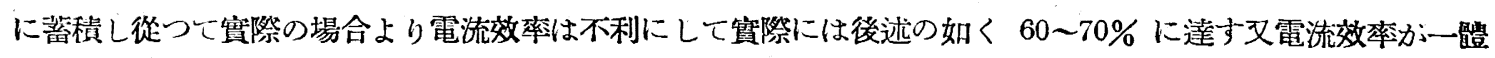
に良好ならざれども此法は交流電力を直搒に使用し得る利益もるが战に此觓點は左程苦にならざるなり

結局の電解反雇方程式

此電解にて生成するものは $\mathrm{MnO}_{2}$ と， $\mathrm{H}_{2}$ なるが故に電解反應の詳細なる機構は乘に盾として結局は次の反 篧方程式に從よものなるべし硝酸冓の場合を例示す 


$$
2 \oplus \Theta+\mathrm{Mn}\left(\mathrm{NO}_{3}\right)_{2}+2 \mathrm{H}_{2} \mathrm{O}=\mathrm{MnO}_{2}+2 \mathrm{HNO}_{3}+\mathrm{H}_{2}
$$

之を璂羷的に證明せんが笉に上記の如き電解液をとり

1. 電解に依る遊離酸の增加を適定に依りて求め

2. 電解にて生成せる $\mathrm{MnO}_{2}$ の生成量を測定し

兩者が果して上記方程式の割合に相當するかを求めたり

遊離酸の湘定には $0.22 N . \mathrm{NaOH}$ を用ひ指示藥としては二三攻究の後マラカイトグリンを適當と認めたり但 し滴定に用みたる電解液は僅 $2 \mathrm{cc}$ に過ぎざりしは稍遺憾なりしが大綱は誤無かるべきを信ず之を中和するに 要する $0.22 N . \mathrm{NaOH}$ 規定液の容量は 6 ～8cc にして電解に依る此容量の督加は 0.5 0.8cc 程度なりき電解 時間を約 30 分に撰びたり長時閒の電解實驗は此試簽の目的には稍不便なりき

$\mathrm{MnO}_{2}$ の定量には先づ過剩の莜酸にて $\mathrm{MnO}_{2}$ を還元し此過剩分を $0.2 N . \mathrm{KMnO}_{4}$ にて旅定して求めたり此 分析には $\mathrm{MnO}_{2}$ か浮游せる電解液を濾別することなく使用せり

使用せる電解液は既述のるのと同濃度にして每团 $200 \mathrm{cc}$ を用ひたり但し硫酸マンガンの第二の場合のみは $150 \mathrm{cc}$ を用ひたり滴定の結果は有效酸素量にて表はし之を比較せり郎ち $\mathrm{MnO}_{2}$ 量よりするものは游定にて求

\begin{tabular}{|c|c|c|c|}
\hline & $\mathrm{MnO}_{2}$ & 酸素量 & めたる $\mathrm{MnO}_{2}$ の有效酸素量を揭げ酸滴定の結果. \\
\hline 硫酸マンガンの場合 & $\begin{array}{l}\text { 遊峈酸增量 } \\
\text { より計算 }\end{array}$ & $\begin{array}{l}\text { 實際 } \mathrm{MnO}_{2} \\
\text { 則 定 量 }\end{array}$ & $\begin{array}{l}\text { よりは遊離酸の堙量が上記反應方程式に從ひたる } \\
\text { ものとして } \mathrm{MnO}_{2} \text { 量を求め之を有効酸素量にて }\end{array}$ \\
\hline 電解實驗第一 & $0.095 \mathrm{~g}$ & $0.102 \mathrm{~g}$ & 表はし前者と比較せり上記反應方程式が傎ならば \\
\hline 第二 & 0.079 & 0.077 & \\
\hline 第三 & 0.132 & 0.169 & 兩者は合致すべきなり實測值を次に揭ぐ \\
\hline $\begin{array}{c}\text { 第四 } \\
\text { 筒酸マンガンの場合 }\end{array}$ & 0.131 & 0.145 & 兩値の間に多少の差異ある場合もあれども酸の \\
\hline 電解凟驗第一 & 0.115 & 0.110 & 滴定には全量の約 $1 \%$ たる 2cc を用ひて滴定し \\
\hline 第二 & 0.126 & 0.116 & たることを考慮に入るれば上記結果は能く既記 \\
\hline
\end{tabular}

反應方程式を證明するものと云ふを得べし

電 解 反應 $\sigma$ 機 構

今硝酸を以て酸性とせる硝酸マンガン水溶液の電解に就て先づ論ぜんと寸

此水溶液に白金電極を用ひ市內動力線よりの交流を通ずるときは液は直ちに其色を變じ幾分紫色を帶びたる 赤色となり液は此色を保持し乍ら直ちに黑褐色の沈澱を生ず但し硝酸酸性弱く且つマンガン監濃度大なる場合 に於ては紫赤色の液を生ずること無く直接黑褐色沈澱を生ず

$\mathrm{Mn}^{++}$は衆知の如く其色淡桃色なり然るに $\mathrm{Mn}^{+++}$は其色紫色を帶びたる赤色なりと云ふ故に上記の電解 液着色は $\mathrm{Mn}^{+++}$の生成に依るものと認められる郎ち電極に於ては次の電解酸化あるべし

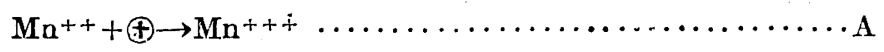

然るに $\mathrm{Mn}^{+++}$及 $\mathrm{Mn}^{++++}$の如き高き酸化階級の重金屬イオンほと酸性的となるを以て其イオンの儘存 在するには强酸性を必要とし酸性弱ければ容易に加水分解して水酸化物、含水の酸化物或は唯の酸化物となり 肹なり例へば次の如し

$$
\begin{aligned}
& \mathrm{Mn}^{+++}+2 \mathrm{H}_{2} \mathrm{O}=\mathrm{MnO}(\mathrm{OH})+3 \mathrm{H}^{+} \ldots \ldots \ldots \ldots \ldots \cdots \cdots \cdot \mathrm{B}
\end{aligned}
$$

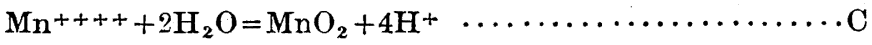

弱酸性にては此電解液が紫赤色を呈せずとの上記の事蕒は之に体りて說明し得べし 
次に $\mathrm{Mn}^{+++}$が或程度蓄樻すれば更に $\mathrm{Mn}^{++++}$か生成するならん其生成法には次の 2 つが可能なる゙へし

其一は直接電解酸化にして

$\mathrm{Mn}^{+++}+\oplus \rightarrow \mathrm{Mn}^{++++} \ldots \ldots \ldots \ldots \cdots \cdots \cdot \mathrm{D}$
$\mathrm{Mn}+++\mathrm{Mn}^{+++} \rightarrow \mathrm{Mn}^{++}+\mathrm{Mn}^{++++} \cdots \cdots \mathrm{E}$

其二は間接にして

兩方とも A 式と組合せて 2 ファラデーの電量にて $\mathrm{Mn}^{++++} \mathrm{g}$ イオン生ずることに變り無し斯くて生じた る $\mathrm{Mn}^{++++}$は最容易に加水分解を受くるが故に $\mathrm{Mn}^{++++}$として大なる濃度に達することなく $\mathrm{C}$ 式に依 り $\mathrm{MO}_{2}$ 或は其加水物に變化し沈澱となるべし

現在著者の智識にて D が主か $\mathrm{E}$ が主かの區別は明かならず黑褐色の沈澱が電極面より生ずることより一見 D の方が主なる樣に見ゆれども又考へ方に依机ば必ずしも然らず郎ち既に $\mathrm{Mn}^{+++}$が濃度充分高くなり將に Eの起らんとする所へ電極面で A に依り更に $\mathrm{Mn}^{+++}$を生じたる䉆烝ら電極附近より $\mathbf{E}$ の反應が生じたる なりとも考へらるるなり故に D カ $\mathrm{E}$ かの判器はつかず唯適當なる條件にて電解を行ふときは $\mathrm{MnO}_{2}$ は電極 面に附着寸る事無く生成するに依り或は E に依るものならんか

之に依り著者の考ふる機蔧は

$$
\mathrm{A} \text {, 次に } \mathrm{D} \text { か } \mathrm{E} \text {, 次に } \mathrm{C}
$$

の順序にて電解力潐行するものなり電極か陰極的になりたるとき $\mathrm{H}^{+}$の放電に依り $\mathrm{H}_{2}$ の發生あり故に是 等を總括せば次の如くなるなり

$$
2 \oplus \Theta+\mathrm{Mn}\left(\mathrm{NO}_{3}\right)_{2}+2 \mathrm{H}_{2} \mathrm{O}=\mathrm{MnO}_{2}+\mathrm{H}_{2}+2 \mathrm{HNO}_{3}
$$

而して陰極的になりたるとき A (若しくはD)の逆が行はるれば之は電流が無効に通過したるものなり又陽摄 的になりたるとき $\mathrm{A}$ (若しくはD)を行はず單に $\mathrm{OH}^{-}$の放電に依る酸素發生を行ひたるものも亦無效なるも のなり

双て此處に興味ある事實は若し酸の濃度、Mn++ の濃度、溫度、電流密度等が一定ならば電解時間の長短 に拘らず紫赤色液の色の濃さが略々一定にして其液の酸化力も亦殆ど定値を與ふる事なり次に二つの例を揭ぐ 電解液を $200 \mathrm{cc}$ 宛取り $25^{\circ}$ にて電解し沈澱を滤過したる液 $50 \mathrm{cc}$ をとり之を $0.0796 N$ の蕯酸にて滴定したる

\begin{tabular}{|c|c|c|c|c|c|}
\hline & & 第 一 & 第 二 & & 郎ち中間體たる $\mathrm{Mn}^{+++}$濃 \\
\hline 電喟液 & $\left\{\mathrm{Mn}^{++}\right.$ & $1.5 \%$ & $1.0 \%$ & & 度が電解條件にて定まる咯 \\
\hline & 電解甠時閐 & 䈪獬溶液酸化力 & 電解時間 & 䨤例液酸化力 & 一定偡に達しては $\mathrm{MnO}_{2}$ \\
\hline & 5 分 & $2.50 \mathrm{cc}$ & 5 分 & $1.30 \mathrm{cc}$ & に變化し淡澱し行くものと \\
\hline & 20 & 2.45 & 30 & 1.30 & 諗めらろ \\
\hline & 60 & 2.48 & & & \\
\hline
\end{tabular}
值を示せり

此紫赤色液を加熱寸れば一方に黑色沈澱 $\left(\mathrm{MnO}_{2}\right)$ を生じ液自身の色は減じ紫色が媣くなる而して此變化に 伴ひ何等有效酸素の損失なし

\section{沈澱の組成及び乾燥}

電解攸件が適當ならば殆ど純粹なる $\mathrm{MnO}_{2}$ (或は其含水物)を沈澱として得べし而して之を $110^{\circ}$ に乾燥す るも何等有效酸素を損失せず

今之を證する實驗の一例を擧げん電解にて得て滤別し洗涤したる嫿の未だ多量の水分を有する沈澱をとり一 方に於ては其內の全 $\mathrm{Mn}$ 量を知る鴟に之を乾燥し且つ坩堝に入れて約 $900^{\circ}$ に灼㷫し之を $\mathrm{Mn}_{3} \mathrm{O}_{4}$ として称 
量せり一方には此濕泌澱を直ちに落酸にて滴定して其有效酸素量（從つて $\mathrm{MnO}_{2}$ 量）を测定して次の結果を 得たり

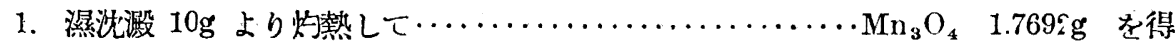

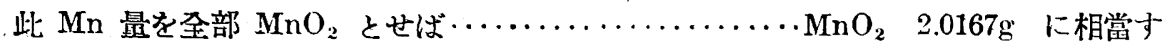

2. 濕瑯澱 $10 \mathrm{~g}$ を滴定し有效酸素を

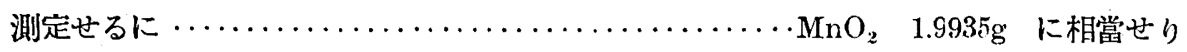

故に此濕沘澱の含有する全 $\mathrm{Mn}$ 中 $\quad 1.9935 / 2.0167=98.9 \% \quad$ が $\mathrm{MnO}_{2}$ の形態にあり

郎ち此濕沈澱中の $\mathrm{Mn}$ は殆ど全部 $\mathrm{MnO}_{2}$ 或は其含水物として存せるなり

次に此濕沘澱を $110^{\circ}$ に乾燥して粉未にしたるものに就て見るに

3. 乾燥粉末 $1 \mathrm{~g}$ 中の全 $\mathrm{Mn}$ 量を知るため之を灼热したるに $\cdot \mathrm{Mn}_{3} \mathrm{O}_{4} \quad 0.8321 \mathrm{~g}$ を得たり 此 $\mathrm{Mn}$ を全部 $\mathrm{MnO}_{2}$ とせば $\ldots \ldots \ldots \ldots \ldots \ldots \ldots \ldots \ldots \mathrm{MnO}_{2} \quad 0.9495 \mathrm{~g}$ に相當す

4. 此乾燥粉末を值ちに苳酸にて滴定し其有效酸素を測走せる

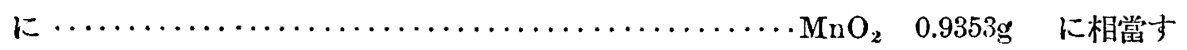

故に此乾燥粉末全 $\mathrm{Mn}$ 中 $0.9353 / 0.9485=98.6 \%$ が $\mathrm{MnO}_{2}$ の形態にあり

郎濕りたる時と名ど變化無し故に $110^{\circ}$ の乾燥中有效酸素の損失無し

好. 適 電 解 佟 件

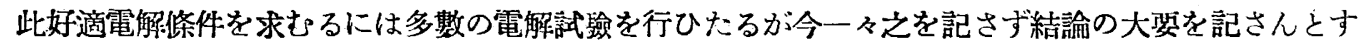

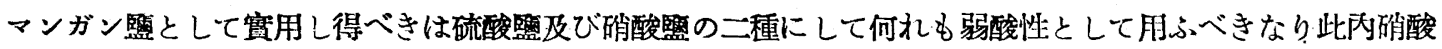
盟の方電流效率良く又二酸化マンガン沈澱の沈降速にして有利なり

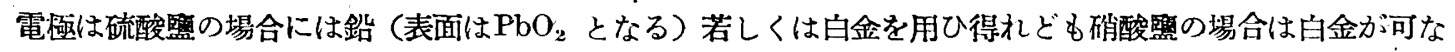
り是等は皆酸化電位高きを得る電極にして更に之を扶くる䉆に電流密度は 5 8 $\mathrm{amp} / \mathrm{cm}^{2}$ の如く大なるを有 利とす故に白金を用ひても白金重量に對して使用電流の比が大にして有利なり

電解液は $\mathrm{Mn}^{++}$の濃度大なるほど電流效率良好なれども餘り濃度大なるときは沈搌は $\mathrm{Mn}_{2} \mathrm{O}_{3}$ を含有寸る 傾向大となり且つ又電極面上に沈澱が固着し其酸化電位を下げて電流效率を惡くす故に邀當なる澧度むり硝酸 笽の時凡そ $\mathrm{Mn}^{++} 3 \%$ 程なり

溫度は高き程酸化速にして且つ沘澱の㳐降も速かなれども餘り高き洔は酸素過電慰低くて宜しからず凡そ $40^{\circ}$ 位を可とす

酸性大なる程電極の酸化力大なる理なれども餘り大なるときは却て電流效率不良なり硝酸賉の場合 $\mathrm{HNO}_{3}$ 2〜3\% を適當とす電解の進行に件ひ酸性增大寸れとど時々炭酸マンガンを加へて酸性を常に此程度に柧節し つつ $\mathrm{Mn}^{++}$を補給するを可とす而して時々泌澱を集めて乾燥し上澄液は電解を繰返へ才

電極は液面近くに置くを便とす沈澱か液面より次第に沈降するを以てなり

少電解液に微量のクロム酸を添加するを甚だ有利なりとす之は電流效率を良くするのみならず沈澱が電極に 附着することを妙ぎ或は一旦附着したるものもクロム酸を加ふれしば脫落ずるの便むり

凡そ電流 2 アムペア電壓 8 ヴォルト位にて 1 時間にて 2 2.8g 程の二酸化マンガンを得べし

1. 適賞なる條件の下にマンガン $\left(\mathrm{Mn}^{++}\right)$覧水浴液を交流にて電解寸れば二酸化マンガンの沈澱を得る事を 
見出せり

2. 其際の電解反應機檏に就て 論ぜり

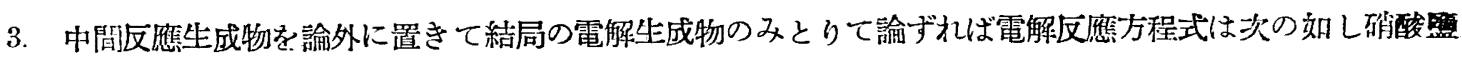
の場合を例示せり

$$
2 \oplus \ominus+\mathrm{Mn}\left(\mathrm{NO}_{3}\right)_{2}+2 \mathrm{H}_{2} \mathrm{O}=\mathrm{MnO}_{2}+2 \mathrm{HNO}_{3}+\mathrm{H}_{2}
$$

4. 好逎電解條件を與へたり

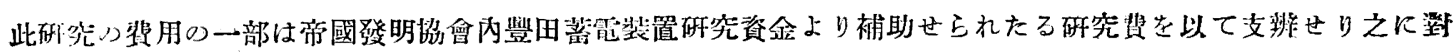
し是處に深き謝意を表す

（東京帝國大學工學部應用管氯化學及光化學研究室）（昭和七年六月八日受理）

\section{交流電解法に依る乾電池用二酸化マンカ}

龜山直人 ·飯田廣

緒言

著者の一人（飯田）がマンガン監の水溶液を適當なる條件の下に交流を以て電解するときは簡易に二酸化マ ンガンを亦し得ることを發見し之に關する著者の科究を先に發表せり（本誌，昭 7,35，907）此製法は二酸化 マンガンの一般製法として與味むるのみならず其製品は乾電池用としても亦良好なる事を認めたり本厗告は其 事實を簡單に報告せんとするものなり

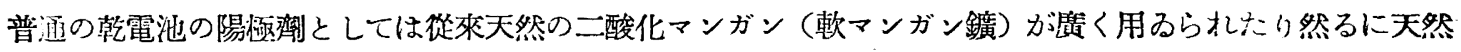
の此鈸不は其 $\mathrm{MnO}_{2}$ 含量大なりと雖必ずしも乾電池用として適當せりと云ふ能はざるのみならず $\mathrm{MnO}_{2}$ 陽

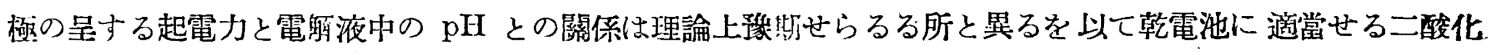

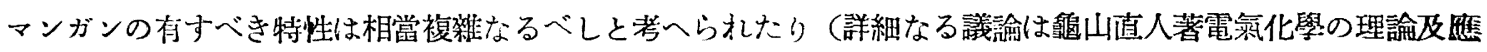

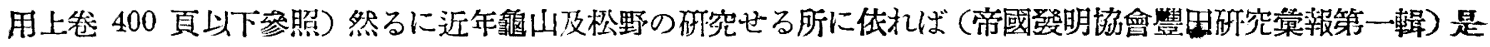
等の關係は從來考へられしほど複雜ならざるが如し郎ち乾電池に適當せる天然二酸化マンガンには特に接觸劑!

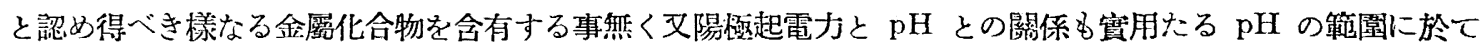
は比較的正規に近し

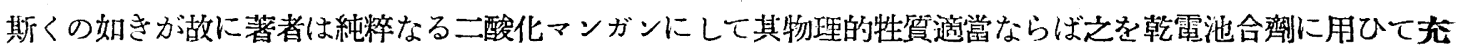
分好結果を得べしとの確信を得たり之を以て諸種の二酸化マンガンの製法を試むる內に既記の如く著者の一人 はマンガン盟水溶液の交流電解にて簡易に二酸化マンガンを得る事を發見しやがて此二酸化マンガンは乾電池 用として適當なるを知り得なり

交流電 解製 法

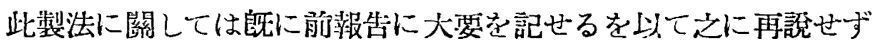

唯注意すべきは電解液中に微量の添加劑を加ふれれば製品の諸性質に或程度の影響を矢へ乾電池用として特に 息好なる製品を得べき事なり

此處に報告する例に於ては硝酸マンガン文原料とせるが其際微量 ( $1 l$ の電解液に $0.2 \mathrm{~g}$ 乃至 $1 \mathrm{~g}$ 程度) のク ロム酸を加へて交流電解して二酸化マンガンを製し之を清水にてよく洗浮し洗淨液は勿論 $\mathrm{CrO}_{4}$ ・の色を呈せ

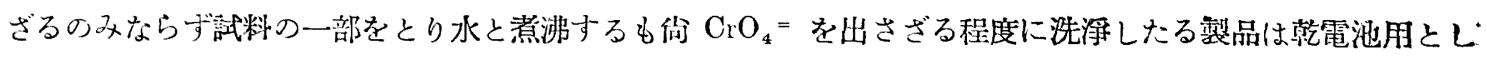

